\title{
A Potential Role for Interleukin-15 in the Regulation of Human Natural Killer Cell Survival
}

\author{
William E. Carson, ${ }^{\star \ddagger}$ Todd A. Fehniger, ${ }^{\ddagger}$ Subrata Haldar, ${ }^{\natural}$ Kenneth Eckhert, ${ }^{\S}$ Matthew J. Lindemann, ${ }^{\ddagger}$ Chun-Fai Lai, \\ Carlo M. Croce, " Heinz Baumann, and Michael A. Caligiuri $\$ \S$ \\ Divisions of ${ }^{*}$ Surgery, ${ }^{\ddagger}$ Molecular Immunology, ${ }^{\S}$ Medicine, and ${ }^{\|}$Molecular Biology, Roswell Park Cancer Center, Buffalo, New York \\ 14263; and ${ }^{\mathbb{K}}$ Kimmel Cancer Institute, Department of Microbiology and Immunology, Jefferson Medical College of Thomas Jefferson \\ University, Philadelphia, Pennsylvania 19104
}

\begin{abstract}
Resting lymphocyte survival is dependent upon the expression of Bcl-2, yet the factors responsible for maintaining lymphocyte Bcl-2 protein expression in vivo are largely unknown. Natural killer (NK) cells are bone marrow-derived lymphocytes that constitutively express the $\beta$ and common $\gamma_{c}$ subunits of the IL-2 receptor (R) as a heterodimer with intermediate affinity for IL-2. IL-15 also binds to IL-2R $\beta \gamma_{c}$ and is much more abundant in normal tissues than IL-2. Mice that lack the IL-2 gene have NK cells, whereas mice and humans that lack IL-2R $\gamma_{c}$ do not have NK cells. Further, treatment of mice with an antibody directed against IL-2R $\beta$ results in a loss of the NK cell compartment. These data suggest that a cytokine other than IL-2, which binds to IL-2R $\beta \gamma_{c}$, is important for NK cell development and survival in vivo. In the current report, we show that the recently described IL-15R $\alpha$ subunit cooperates with IL-2R $\beta \gamma_{c}$ to transduce an intracellular signal at picomolar concentrations of IL-15. We demonstrate that resting human NK cells express IL-15R $\alpha$ mRNA and further, that picomolar amounts of IL-15 can sustain NK cell survival for up to $8 \mathrm{~d}$ in the absence of serum. NK cell survival was not sustained by other monocyte-derived factors (i.e., TNF- $\alpha$, IL-1 $\beta$, IL-10, IL-12) nor by cytokines known to use $\gamma_{c}$ for signaling (i.e., IL-4, IL-7, IL-9, IL- 13). One mechanism by which IL-15 promotes NK cell survival may involve the maintenance of Bcl-2 protein expression. Considering these functional properties of IL-15 and the fact that it is produced by bone marrow stromal cells and activated monocytes, we propose that IL-15 may function as an NK cell survival factor in vivo. (J. Clin. Invest. 1997. 99:937-943.) Key words: natural killer cells • interleukin $15 \cdot \mathrm{IL}-15 \mathrm{R} \alpha \cdot$ apoptosis $\bullet \mathrm{Bcl}-2$
\end{abstract}

\section{Introduction}

Human natural killer $(\mathrm{NK})^{1}$ cells are large granular lymphocytes that display non-MHC restricted cytotoxicity against malignant and virally infected cells without prior sensitization (1, 2 ). We have shown that NK cells rapidly undergo programmed

Address correspondence to Michael A. Caligiuri, Roswell Park Cancer Institute, Buffalo, NY 14263-0001. Phone: 716-845-3087; FAX: 716-845-2343; E-mail: caligiuri@dm3100.med.buffalo.edu

Received for publication 14 August 1996 and accepted in revised form 10 December 1996.

J. Clin. Invest.

(C) The American Society for Clinical Investigation, Inc.

0021-9738/97/03/0937/07 \$2.00

Volume 99, Number 5, March 1997, 937-943 cell death (PCD) when cultured under serum-free conditions in vitro (3). NK cells are therefore likely to depend upon extracellular factors for their continued survival in vivo. The majority of NK cells constitutively express an intermediate affinity IL-2 receptor (IL-2R), which is composed of $\beta$ and common gamma $\left(\gamma_{c}\right)$ subunits $(4,5)$. Whereas IL-2 could be an important cytokine for NK cell survival in vivo, its production appears to be limited to activated T cells that bind IL-2 with 10-100-fold higher affinity than do NK cells (6). Further, T cell-deficient mice have NK cells (7), as do mice that bear a genetically disrupted IL-2 gene $(8,9)$. In contrast, mice and humans who lack IL-2R $\gamma_{c}$ do not have NK cells $(10,11)$, and treatment of mice with antibody directed against IL-2R $\beta$ results in rapid loss of the NK cell compartment (12). Collectively, these data suggest that cytokines other than IL-2 that utilize the $\beta$ and $\gamma_{c}$ components of the IL-2R might be important for NK development and survival in vivo.

The human $I L-15$ gene transcript is constitutively expressed in a variety of normal tissues including placenta, skeletal muscle, kidney, lung, liver, and pancreas (13). The IL-15 protein has been identified in culture supernatants of human bone marrow stromal cells and activated human monocytes $(14,15)$. IL-15 has no sequence homology with IL-2 (13), yet is able to activate NK cells via the $\beta$ and $\gamma_{c}$ subunits of the IL-2R $(16,17)$. IL-15 uses its own $\alpha$ chain (IL-15R $\alpha$ ) for high affinity IL-15 binding $(18,19)$. In this report, we examine human NK cells for IL-15R $\alpha$ expression and assess the effects of IL-15 on NK cell survival in vitro.

\section{Methods}

Cytokines. Purified, yeast-derived, recombinant (r) human (h) IL-15 was obtained from Immunex Research and Development Corp. (Seattle, WA). rhIL-2 was provided by Hoffman LaRoche (Nutley, NJ) (specific activity, $1.53 \times 10^{7} \mathrm{U} / \mathrm{mg}$ purified protein). rhIL-10 was provided by Schering-Plough Research Institute (Kenilworth, NJ) (specific activity, $2.3 \times 10^{7} \mathrm{U} / \mathrm{mg}$ purified protein). Purified rhIL-12 (specific activity of $4.5 \times 10^{6} \mathrm{U} / \mathrm{mg}$ ) was provided by Genetics Institute Inc. (Cambridge, MA). Purified rhIL-1 $\beta$, rhTNF- $\alpha$, rhIL-4, rhIL-7, rhIL-9, rhIL-10, and rhIL-13 were purchased from R \& D Systems (Minneapolis, MN). All cytokines were reconstituted in RPMI-1640 supplemented with $0.1 \%$ human albumin (Armour Pharmaceutical Co., Kankakee, IL).

Cell lines. P815 is an NK-resistant murine mastocytoma cell line which served as the target in antibody-dependent cellular cytotoxicity (ADCC) assays (16). K562, a human chronic myelogenous leukemia cell line was used in cytotoxicity assays and served as a positive con-

1. Abbreviations used in this paper: ADCC, antibody-dependent cellular cytotoxicity; E, effector; h, human; NK, natural killer; ODN, oligodeoxynucleotide; PI, propidium iodide; r, recombinant; SFM, serum-free medium; T, target. 
trol for expression of the IL-15R $\alpha$ transcript in Northern blot analyses (19). Jurkat, a human acute T cell leukemia cell line, was used as a negative control (19). These cell lines were grown in RPMI-1640 supplemented with $10 \%$ heat-inactivated FCS (Sigma Chemical Co., St. Louis, MO), anti-PPLO agent, and antibiotics. NK-92 is a $\mathrm{CD}^{-}{ }^{-} \mathrm{CD} 56^{+} \mathrm{NK}$ cell leukemia cell line (20) (kindly provided by Dr. Hans G. Klingermann, Vancouver, Canada), which was grown in RPMI-1640 medium supplemented with $10 \mathrm{ng} / \mathrm{ml}$ IL-2 or IL- $15,20 \%$ FCS, and antibiotics.

Isolation and culture of human NK cells. Human NK cells were obtained from fresh leukopacs (American Red Cross, Buffalo, NY) and enriched to $\geq 97 \%$ purity using immunomagnetic bead depletion and fluorescent-activated cell sorting as previously described (21). $\mathrm{CD} 6^{+}$NK cells were cultured in serum-free medium (SFM: RPMI1640 media plus anti-PPLO agent and antibiotics), and unless otherwise stated, addition of cytokines was made only at the initiation of cell cultures.

Flow cytometric measurement of Bcl-2. Sorted human NK cells used for analysis were harvested from culture, centrifuged at 1,100 $\mathrm{rpm}$, and then permeabilized by incubation in ORTHO PermeaFix (Johnson and Johnson, Raritan, NJ) for $30 \mathrm{~min}$ at $4^{\circ} \mathrm{C}$. Cells were washed twice, resuspended in $100 \mu \mathrm{l}$ of PBS, and incubated with mouse anti-human Bcl-2-FITC-conjugated mAb (DAKO, Carpinteria, CA) for $30 \mathrm{~min}$ at $4^{\circ} \mathrm{C}$. A FITC-conjugated nonreactive $\mathrm{IgG}_{1} \mathrm{mu}$ rine $\mathrm{mAb}$ (Becton-Dickinson, Mountain View, CA) was used to stain parallel samples of human NK cells and served as a control for nonspecific fluorescence. Cells were washed once in PBS, fixed in $1 \mathrm{ml}$ of $1 \%$ paraformaldehyde, and analyzed for fluorescence intensity on a FACScan $^{\circledR}$. Data was processed using the LYSIS II software program (Becton-Dickinson) (22).

Assessment of DNA cleavage by propidium iodide staining. Analysis of individual propidium iodide (PI)-stained cell nuclei via flow cytometry was used to obtain a quantitative measurement of apoptosis as described (23). 10,000 PI-stained nuclei were then analyzed for fluorescence intensity on a FACScan ${ }^{\circledR}$, and data were processed using the LYSIS II software program (Becton-Dickinson).

${ }^{51}$ Chromium release cytotoxicity assay. Assays were performed using sorted $\mathrm{CD}_{56} 6^{+} \mathrm{NK}$ cells that had been plated $7 \mathrm{~d}$ earlier in the presence or absence of IL-15. Without further manipulation, the day 7 NK cells were admixed with ${ }^{51} \mathrm{Cr}$-labeled K562 or P815 target cells for NK cytotoxicity or ADCC assays, respectively, at an effector (E) to target (T) ratio of 5:1. P815 target cells were preincubated with either medium alone or a 1:100 dilution of polyclonal rabbit antimouse lymphocyte serum (Accurate Chemical and Scientific Corp., Westbury, NY) as previously described (16). In a second set of experiments, remaining viable cells were sorted by size and granularity from 7-d cultures with SFM or SFM plus IL-15 and then plated in a cytotoxicity assay with ${ }^{51} \mathrm{Cr}$-labeled $\mathrm{K} 562$ target cells at an E:T ratio of 5:1.

Western blotting. NK cells used for immunoblot analysis (purity $\geq 97 \%$ ) were prepared as previously described (3). Equal numbers of cells were used from each experimental condition. Sample identity was unknown to the investigator quantitating the protein and conducting the immunoblot analysis. Lysates were quantitated, equally loaded (100 $\mu \mathrm{g}$ per lane), separated by SDS-PAGE, and transferred to nitrocellulose. Nitrocellulose sheets were probed with an anti-Bcl-2 $\mathrm{mAb}$ (Cambridge Research Biochemical) as previously described (3).

Preparation of oligonucleotides. The bcl-2 antisense oligodeoxynucleotide (ODN) straddles the predicted translation-initiation site of human $b c l-2$ mRNAs and is complementary to this region. The scrambled missense (negative control) ODN does not exhibit homology with other genes (22). Phosphothioate ODNs were prepared, purified, and resuspended as described (3). $10 \mu \mathrm{M} \mathrm{bcl-2}$ missense or antisense was added to cultures of CD56 ${ }^{+}$NK cells daily, as described (3).

Northern blot analysis of IL-15R $\mathrm{mRNA}$. Resting NK cells (>90\% purity) were analyzed for IL-15R $\alpha$ transcript immediately after isolation via immunomagnetic bead depletion. Total RNA was reacted with glyoxal at $50^{\circ} \mathrm{C}$ for $1 \mathrm{~h}$ to remove secondary structure. Equal amounts of RNA ( $20 \mu \mathrm{g}$ per lane) were size fractionated by electrophoresis on a $1.2 \%$ agarose gel and then transferred to Zeta Probe GT nylon membranes (Bio-Rad, Hercules, CA) by capillary action and cross-linked to filters by UV irradiation. Blots were subsequently hybridized with ${ }^{32} \mathrm{P}-\mathrm{dCTP}-$ labeled cDNA probes for $12 \mathrm{~h}$ at $65^{\circ} \mathrm{C}$. After two washes, hybridized membranes were exposed to X-OMAT AR film (Eastman Kodak Co., Rochester, NY) at $-70^{\circ} \mathrm{C}(24)$. The cDNA probe for human IL-15R $\alpha$ was provided by the Immunex Corp., (Seattle, WA).

Transfection of $I L-2 R \alpha, I L-2 R \beta, I L-2 R \gamma$, and $I L-15 R \alpha$. The human hepatoma cell line HepG2 (25) was cultured in minimal essential medium supplemented with $10 \%$ FCS and antibiotics and was transfected using the calcium phosphate method as previously described (26). Cytokine response of transfected cells was defined by stimulation of the pHRRE-CAT reporter gene construct, which contains eight tandem copies of the hematopoietin receptor response element
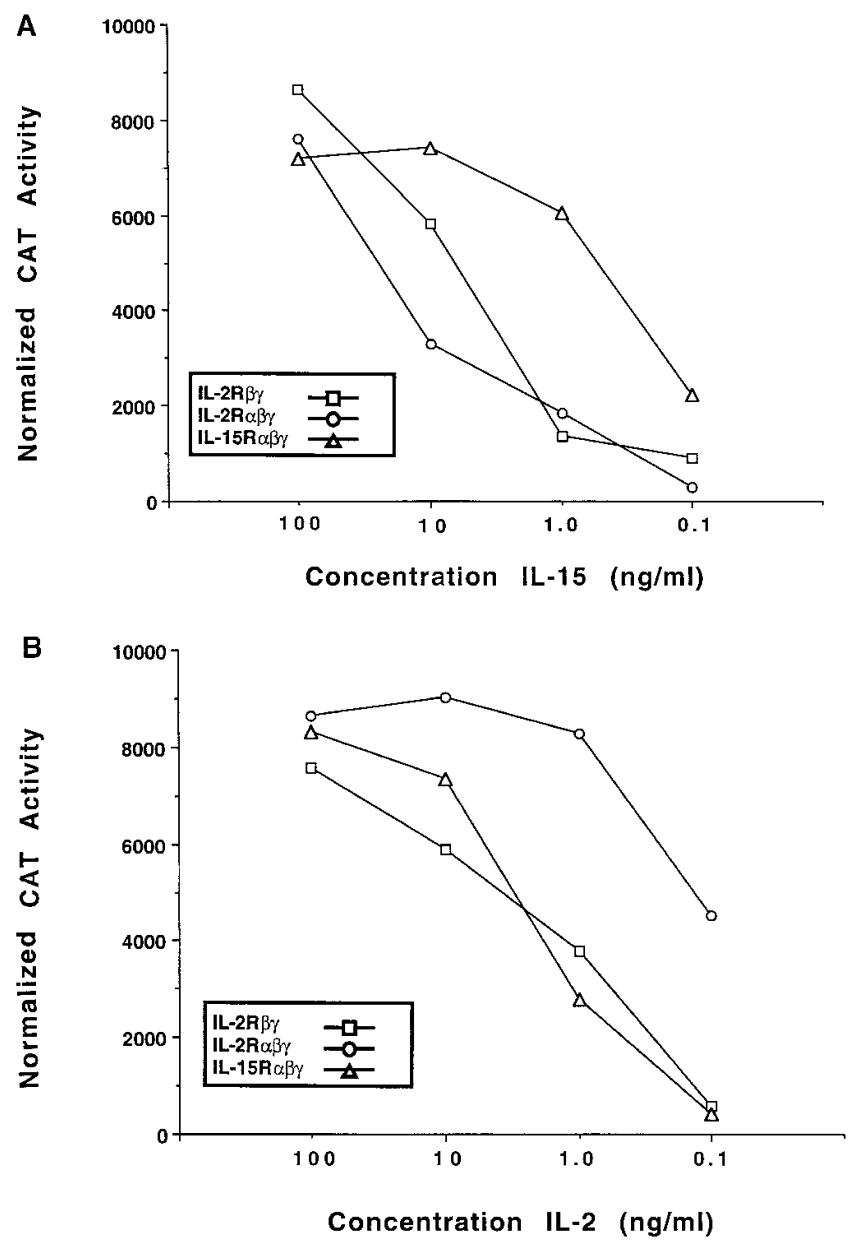

Figure 1. (A) Effect of IL-15 on gene activation in transient transfectants expressing subunits of the IL-2R and IL-15R complexes. HepG2 cells were transfected with the HRRE-CAT reporter construct, the expression vectors for the indicated IL-2R subunits, and a major urinary protein (MUP) expression vector (control). Cultures were treated with the concentration of IL-15 denoted on the $\mathrm{x}$-axis $(0.1 \mathrm{ng} / \mathrm{ml}=7 \mathrm{pM}) .(B)$ Effect of IL-2. Constructs were identical to those shown in $A$. Cultures were treated with the concentration of IL-2 denoted on the $\mathrm{x}$-axis $(0.1 \mathrm{ng} / \mathrm{ml}=7 \mathrm{pM})$. The CAT activity in both experiments was calculated using MUP for normalization. Results shown are representative of at least four independent experiments. 
(HRRE) sequence (27). Cells were transfected with plasmid DNA mixtures consisting of $15 \mu \mathrm{g}$ of CAT plasmid and $1 \mu \mathrm{g}$ of the expression vectors for the IL-2R $\beta$ and IL- $2 R \gamma_{c}$ subunits alone or in combination with $1 \mu \mathrm{g}$ of either the IL-2R $\alpha$ or IL-15R $\alpha$ expression vectors (27). An expression vector for major urinary proteins (pIE-MUP, $2 \mu \mathrm{g}$ ) served as an internal transfection marker. After a $16 \mathrm{~h}$ recovery period, the transfected cell culture was subdivided into a 6-well cluster plate, and $24 \mathrm{~h}$ later the subcultures were treated with the indicated concentrations of IL-2 or IL-15. The CAT activity in cell extracts was determined and normalized to the amount of the major urinary proteins derived from pIE-MUP in each culture (27). The values represent percent chloramphenicol conversion of substrate to acetylated products per hour and nanogram MUP.

\section{Results}

Coexpression of the IL-15R $\alpha$ chain with the IL-2R $\beta \gamma_{c}$ heterodimer confers $C A T$ activity in response to picomolar concentrations of IL-15. To evaluate whether IL-15R $\alpha$ contributes to enhanced IL-15 signaling efficiency, we first determined its role in a heterologous cell system in which the function of the IL-2/IL-15R subunits could be reconstituted. HepG2 hepatoma cells, which are deficient of any IL-2R or IL-15R subunits, were transiently transfected with expression vectors for the IL- $2 \mathrm{R} \gamma_{\mathrm{c}}$, IL-2R $\beta$, IL-2R $\alpha$, or the IL- $15 \mathrm{R} \alpha$ subunits along with a CAT reporter construct responsive to the gene inducing signals of the IL-2R. Transfection of IL-15R $\alpha$ into cells expressing the IL- $2 R \beta \gamma_{c}$ resulted in substantial CAT activity (i.e., $\geq 2,000)$ at picomolar concentrations of IL-15 that were 10-fold lower than those required for equivalent CAT activity in the IL-2R $\beta \gamma_{c}$ or IL-2R $\alpha \beta \gamma_{c}$ transfectants. For CAT activity between 2,000 and 8,000, IL-15R $\alpha \beta \gamma_{\mathrm{c}}$ transfectants required $\sim 10-100$-fold lower concentrations of IL-15 compared with IL-2R $\beta \gamma_{c}$ or IL-2R $\alpha \beta \gamma_{c}$ transfectants (Fig. $1 A$ ). Transfection of IL-2R $\alpha$ into cells expressing the IL-2R $\beta \gamma_{c}$ did not enhance sensitivity to IL-15 (Fig. $1 \mathrm{~A}$ ). In contrast, the IL-15R $\alpha \beta \gamma_{\mathrm{c}}$ transfectant did not show enhanced responsiveness to IL-2, compared with that seen in the IL-2R $\alpha \beta \gamma_{\mathrm{c}}$ transfectant (Fig. $1 B$ ).

Freshly isolated human NK cells express transcript for the $I L-15 R \alpha$ chain. We previously provided evidence for high affinity binding of radiolabeled IL-15 to enriched populations of human NK cells by Scatchard analysis (16). However, IL-15R $\alpha$ chain expression in human NK cells has not been described. Total cellular RNA was isolated from fresh NK cells and shown to contain IL-15R $\alpha$ mRNA by Northern blot (Fig. 2).

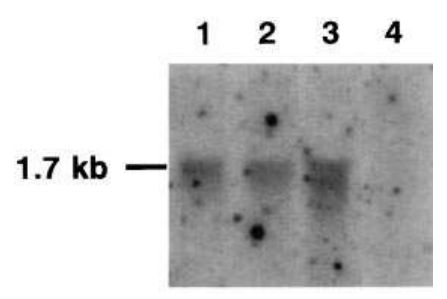

Figure 2. Expression of the IL-15R $\alpha$ gene product in human NK cells. Total RNA from enriched (purity $\geq 90 \%$ ) NK cells or control cell lines was subjected to Northern blot analysis using a full length cDNA probe for human IL$15 \mathrm{R} \alpha$. Lanes 1 and 2 , fresh NK cells from two individuals; 3 , human K562 cell line (positive control, reference 19); 4, Jurkat cell line (negative control, reference 19). UV flourescence of ethidium bromidestained 18 sRNA is shown below each lane as a measure of RNA loading.

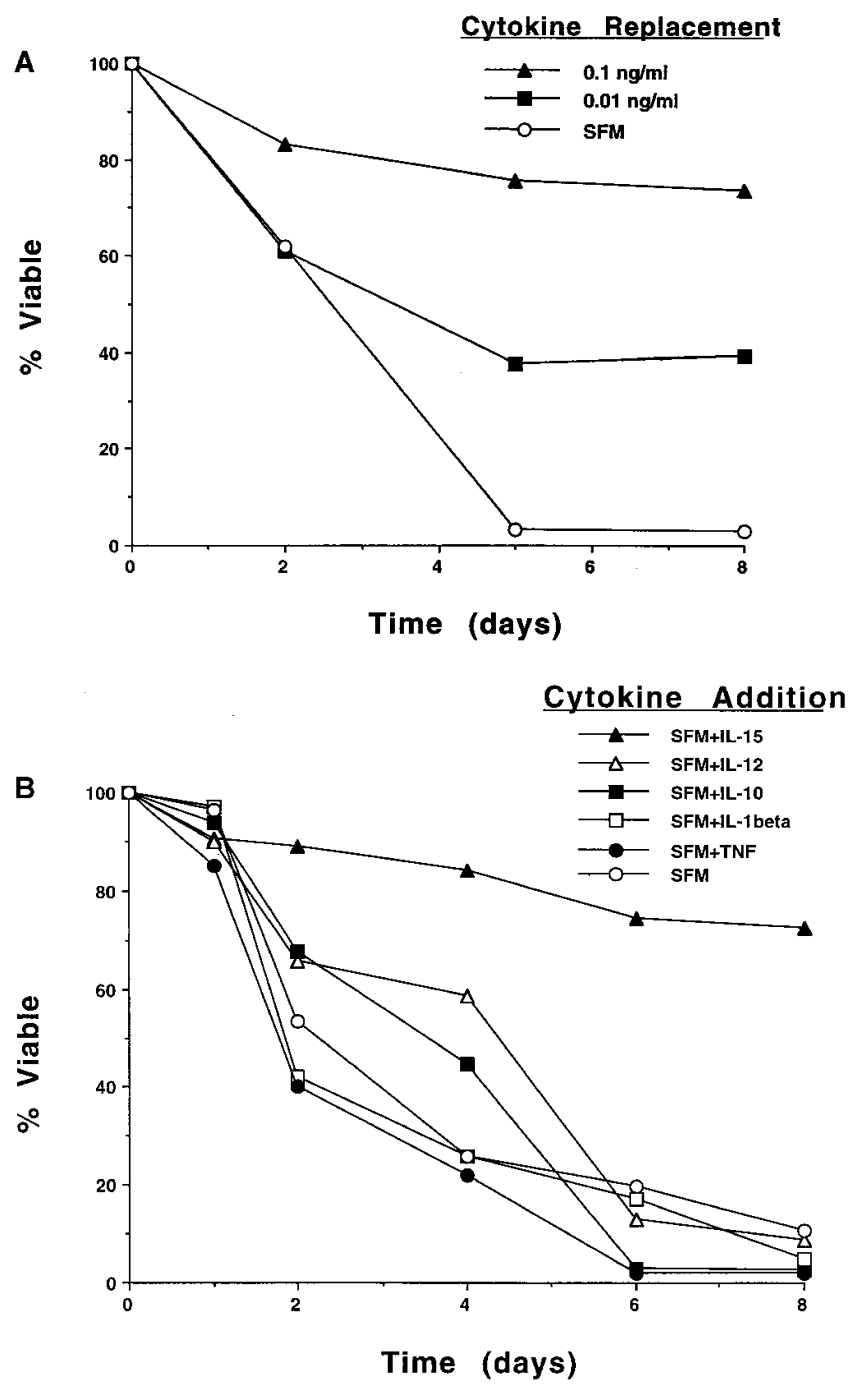

Figure 3. Low (pM) concentrations of IL-15 promote NK cell survival in serum free medium. Purified ( $\geq 97 \%$ ) CD $56^{+}$human NK cells were isolated from the blood of normal donors and cultured at $37^{\circ} \mathrm{C}$ in serum-free medium (SFM) in the presence or absence of cytokines. Cell viability was determined for duplicate wells at the indicated times via vital dye exclusion and is expressed as a percentage of the total number of cells present at the initiation of culture $\left(3 \times 10^{5}\right.$ cells/well). ( $A$ ) NK cells cultured in SFM supplemented with either $0.01 \mathrm{ng} / \mathrm{ml} \mathrm{IL-15}(0.7 \mathrm{pM}), 0.1 \mathrm{ng} / \mathrm{ml} \mathrm{IL-15}$, or SFM alone. $50 \%$ of supernatant was replaced daily. $(B)$ NK cells cultured in SFM or SFM supplemented with IL-15 (10 ng/ml or $0.7 \mathrm{nM})$, IL-12 $(10 \mathrm{ng} / \mathrm{ml})$, IL-10 (10 ng/ml), IL-1 $\beta$ (10 ng/ml), or TNF- $\alpha(300 \mathrm{U} / \mathrm{ml})$. Cytokine additions were made only at the initiation of culture. Results shown are representative of at least four independent experiments. Standard error for each time point was $<5 \%$.

Interleukin-15 promotes the survival of NK cells in SFM. Picomolar concentrations of IL-15 do not stimulate significant NK cell proliferation, cytotoxicity, or cytokine production (16). To test if IL-15 might act as an NK cell survival factor at low concentrations, fresh NK cells were cultured in SFM in the presence or absence of picomolar concentrations of IL-15. Cell viability was assessed by vital dye exclusion. IL-15 at $0.01 \mathrm{ng} /$ $\mathrm{ml}(0.7 \mathrm{pM})$ and $0.1 \mathrm{ng} / \mathrm{ml}(7.0 \mathrm{pM})$ sustained $\mathrm{NK}$ survival over a period of $8 \mathrm{~d}$ when medium was replaced daily, compared 
Table I. Effect of $\gamma_{c}$ Chain Cytokines on the Viability of Human NK Cells Cultured in Serum-free Medium

\begin{tabular}{lcccccr}
\hline & Day 0 & Day 2 & Day 4 & Day 6 & Day 8 & Day 9 \\
\hline $\begin{array}{l}\text { Cytokine* } \\
\text { IL-15 }\end{array}$ & 100 & 80 & 79 & 80 & 76 & 72 \\
IL-2 & 100 & 86 & 73 & 79 & 75 & 75 \\
IL-13 & 100 & 73 & 39 & 30 & 10 & 0 \\
IL-9 & 100 & 76 & 40 & 32 & 10 & 2 \\
IL-7 & 100 & 51 & 34 & 23 & 10 & 12 \\
IL-4 & 100 & 85 & 56 & 33 & 12 & 12 \\
HAB $^{\ddagger}$ & 100 & 87 & 53 & 29 & 9 & 10 \\
SFM $^{\S}$ & 100 & 72 & 41 & 28 & 11 & 10 \\
& & & & & & \\
\hline
\end{tabular}

$* 3 \times 10^{5}$ purified human NK cells were cultured in serum-free medium $(S F M)$ alone or SFM supplemented with $10 \mathrm{ng} / \mathrm{ml}$ of the indicated cytokine. Cytokine additions were made only at the initiation of culture. Viability was determined via vital dye exclusion assay. ${ }^{\ddagger}$ Viability of NK cells cultured in RPMI-1640 medium supplemented with $10 \%$ human AB serum. ${ }^{\S}$ Serum-free medium.

with no survival in SFM alone (Fig. $3 A$ ). In a similar experiment, other monocyte-derived cytokines known to act on NK cells (i.e., IL-1 $\beta$, TNF- $\alpha$, IL-10, and IL-12) did not promote NK survival in SFM (Fig. $3 B$ ).

IL-2, IL-4, IL-7, IL-9, and possibly IL-13 also use the $\gamma_{\mathrm{c}}$ constitutively expressed by NK cells $(28,29)$. We therefore tested whether any of these cytokines could promote NK cell survival in SFM at a concentration of $10 \mathrm{ng} / \mathrm{ml}$. As shown in Table I, only IL-15 and IL-2 could sustain NK survival under the conditions of this in vitro assay.
IL-15 prevents programmed cell death of NK cells. NK cells undergo programmed cell death when cultured in SFM (3). Microscopic analysis of CD56 ${ }^{+}$cells that were cultured for $24 \mathrm{~h}$ in SFM revealed the characteristic features of cytoplasmic volume loss, membrane blebbing, and nuclear condensation, which are indicative of apoptosis (30). In contrast, cells cultured in $10 \mathrm{ng} / \mathrm{ml}$ IL-15 exhibited none of these features and appeared fully viable (not shown). DNA isolated from fresh NK cells cultured for $24 \mathrm{~h}$ in SFM and $10 \mathrm{ng} / \mathrm{ml}(0.7 \mathrm{nM}) \mathrm{IL}-15$ showed no DNA fragmentation on electrophoretic analysis, while DNA from NK cells cultured in SFM for $24 \mathrm{~h}$ showed a classic laddering pattern indicative of the onset of apoptosis (data not shown).

A quantitative measure of apoptosis by nuclear staining with PI and flow cytometry was used to further evaluate the effect of IL-15 on NK cell survival (3). Apoptotic nuclei appear within the hypodiploid region of the DNA histogram due to the endonucleolytic cleavage of DNA, whereas the PI fluorescence of viable cells with diploid DNA content falls within a characteristic band of constant intensity (23). NK cells were cultured in SFM supplemented with varying concentrations of IL-15 and the percentage of cells appearing within the apoptotic fraction was determined over time via flow cytometry. Representative results from 3-d cultures of $\mathrm{CD}^{+} 6^{+} \mathrm{NK}$ cells are shown in Fig. 4, $A-D$. At $72 \mathrm{~h}$, there was marked cleavage of DNA in NK cells, which had been cultured in SFM alone (97\%), whereas the addition of IL-15 at concentrations of 0.1 , 1.0 , and $10 \mathrm{ng} / \mathrm{ml}$ inhibited this process $(36,17$, and $8 \%$ apoptosis, respectively). Thus, IL-15 prevented the apoptosis of NK cells in a dose-dependent fashion, possibly reflecting exhaustion of the exogenously added cytokine. Moreover, the absence of a hyperdiploid peak in the DNA histograms illustrates that IL-15 does not induce significant NK cell proliferation in

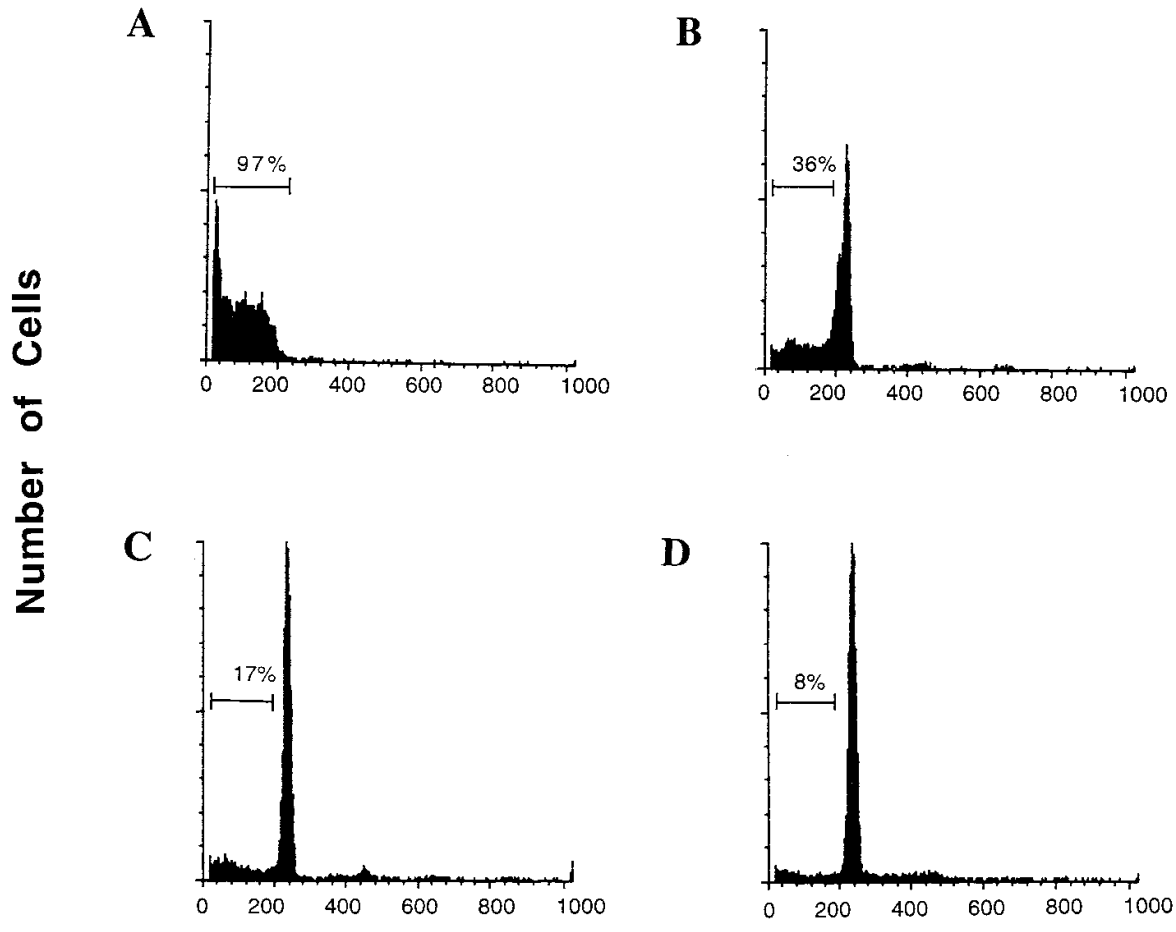

DNA Content (PI fluorescence)
Figure 4. IL-15 inhibits programmed cell death in NK cells in a dose-dependent fashion. A quantitative measurement of apoptosis was obtained by staining cellular DNA with PI and measuring the fluorescence of individual nuclei by flow cytometry. Apoptotic nuclei appear within the hypodiploid region of the DNA histogram due to the endonucleolytic cleavage of DNA, whereas the fluorescence of cells with diploid DNA content falls within a characteristic band of constant intensity (23). (A) Purified NK cells ( $\geq 97 \%$ ) cultured in SFM for $72 \mathrm{~h} .(B-D)$ NK cells cultured in SFM plus $0.1 \mathrm{ng} / \mathrm{ml}(0.7 \mathrm{pM}), 1.0$ $\mathrm{ng} / \mathrm{ml}$, or $10 \mathrm{ng} / \mathrm{ml} \mathrm{IL}-15$ for $72 \mathrm{~h}$, respectively. These results are representative of ten separate experiments. 
short-term culture. Taken together, these data suggest that IL-15 prevents programmed cell death of NK cells.

IL-15 sustains the functional viability of NK cells in SFM. We next determined if NK cells cultured in IL-15 had retained functional integrity in addition to membrane and DNA integrity. NK cells were cultured in SFM with or without IL-15 (1 ng/ $\mathrm{ml})$ and tumor cell targets were then added directly to wells to assess NK cytotoxicity and ADCC. NK cells cultured in SFM without IL-15 for $7 \mathrm{~d}$ did not display any NK cytotoxic activity against K562 target cells or antibody-coated P815 target cells at an E:T of 5:1. In contrast, NK cells maintained in SFM with $1.0 \mathrm{ng} / \mathrm{ml}(70 \mathrm{pM}) \mathrm{IL}-15$ for $7 \mathrm{~d}$ exhibited $64 \pm 0.9 \%$ cytotoxic activity against $\mathrm{K} 562$ cells and $56 \pm 2.0 \% \mathrm{ADCC}$ at the same E:T. These experiments were repeated two additional times with similar results. In a second set of experiments, viable cells were sorted out from 7-d cultures in SFM alone (0.6\% of total cells) and compared with an equal number of viable cells sorted out from 7-d cultures in SFM plus IL-15 (28.7\%). In this instance, cytotoxicity of viable cells against K562 was equivalent ( $\sim 10 \%$ at an E:T ratio of 5:1). The dose of IL-15 used in these experiments $(1.0 \mathrm{ng} / \mathrm{ml})$ was previously shown not to significantly enhance NK cell cytotoxic activity (16).

IL-15 maintains Bcl-2 protein levels in NK cells cultured in $S F M$. CD56 ${ }^{+} \mathrm{NK}$ cells were isolated from fresh blood and cultured for $24 \mathrm{~h}$ in SFM supplemented with $10 \mathrm{ng} / \mathrm{ml} \mathrm{IL-15}$ or an equal volume of carrier solution. Cell lysates from fresh and cultured NK cells were quantitated in a blinded fashion, equally loaded, and subjected to immunoblot analysis. NK cells cultured for $24 \mathrm{~h}$ in SFM supplemented with IL-15 exhibited $\mathrm{Bcl}-2$ protein levels that were roughly equivalent to those seen in fresh NK cells, whereas NK cells cultured for $24 \mathrm{~h}$ in SFM alone expressed barely detectable levels of Bcl-2 protein (Fig. 5). An aliquot of cells from each experimental condition was examined for membrane integrity by vital dye exclusion and for morphology by cytospin preparation. Whereas cells from all three conditions retained membrane integrity at $24 \mathrm{~h}$, morphologic changes consistent with apoptosis were seen only in cells cultured in SFM alone (not shown).

IL-15 cannot sustain human NK cell survival in the presence of bcl-2 antisense. To further delineate the relationship between IL-15, Bcl-2 expression, and NK cell survival, we made use of a $b c l-2$ antisense ODN. We have previously demonstrated that a nuclease-resistant phosphothiorate antisense ODN directed against bcl-2 mRNA specifically inhibits Bcl-2 protein production, whereas the missense version of this ODN is inactive at similar concentrations (22). Freshly isolated NK

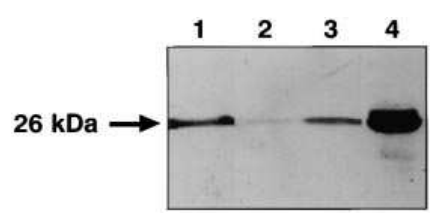

Figure 5. IL-15 maintains Bcl-2 protein levels in human NK cells. Immunoblot analysis. $5 \times$ $10^{6}$ NK cells were used for each condition. Each lane was loaded with $100 \mu \mathrm{g}$ of protein from NK cell lysates which were quantitated in a blinded fashion at the time of electrophoresis and subsequently subjected to immunoblot analysis with an anti-Bcl-2 mAb. Lane: 1 , freshly isolated ( $\geq 97 \%$ ) NK cells. Lane 2 , NK cells from the same donor as lane 1 which were cultured in SFM alone for $24 \mathrm{~h}$. Lane 3, NK cells from the same donor as lane 1 which were cultured in SFM plus $10 \mathrm{ng} / \mathrm{ml} \mathrm{IL-15}$ for $24 \mathrm{~h}$. Lane 4 , lysate of the pre-B cell line 380 that expresses high levels of Bcl-2 (22). Results shown are representative of four separate experiments.

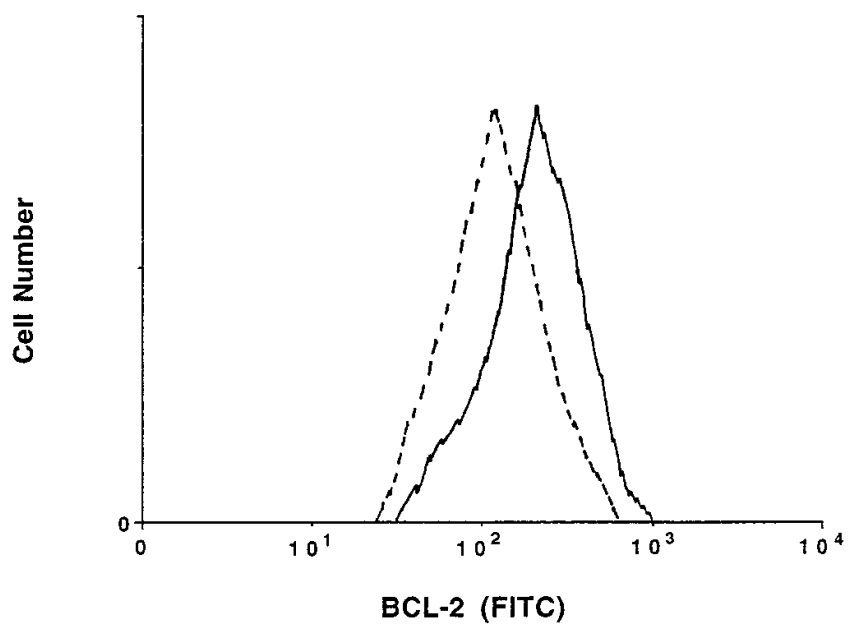

Figure 6. IL-15 cannot sustain human NK cell survival in the presence of bcl-2 antisense. CD56 ${ }^{+} \mathrm{NK}$ cells were purified from fresh blood by fluorescent activated cell sorting. After a 48-h incubation in the presence of SFM, $0.75 \mathrm{ng} / \mathrm{ml} \mathrm{IL-15}$, and either $10 \mu \mathrm{M} \mathrm{bcl-2}$ antisense ODN or $10 \mu \mathrm{M} \mathrm{bcl-2}$ missense ODN (control), cells were harvested and assessed for $\mathrm{Bcl}-2$ protein expression via flow cytometry using the gate for viable lymphocytes. (Solid line) NK cells treated with missence $b c l-2$ (viability $=94 \pm 4 \%)$. (Dashed line) NK cells treated with antisense $b c l-2$ (viability $=32 \pm 10 \%$ ) This experiment is representative of three separate determinations, each with similar results.

cells were cultured in SFM with $0.75 \mathrm{ng} / \mathrm{ml}$ IL- 15 and $10 \mu \mathrm{M}$ of $b c l-2$ missense ODN (control) or in SFM with $0.75 \mathrm{ng} / \mathrm{ml} \mathrm{IL-15}$ and $10 \mu \mathrm{M}$ of $b c l-2$ antisense ODN. Cultures were assessed daily for cell viability by vital dye exclusion assay and for Bcl-2 expression by flow cytometry. At $48 \mathrm{~h}$, NK cells cultured with $10 \mu \mathrm{M}$ of the control ODN exhibited Bcl-2 levels equivalent to those of fresh NK cells, whereas the cells cultured in $10 \mu \mathrm{M}$ of the $b c l-2$ antisense ODN had reduced levels of Bcl-2 (Fig. 6). In three separate experiments, NK cells cultured in the presence of $0.75 \mathrm{ng} / \mathrm{ml}$ IL-15 and $10 \mu \mathrm{M}$ of the control ODN were $94 \pm 4 \%$ viable by vital dye exclusion, whereas the cells cultured for $3 \mathrm{~d}$ in the presence of $0.75 \mathrm{ng} / \mathrm{ml}$ IL-15 and $10 \mu \mathrm{M}$ of the $b c l-2$ antisense ODN were $32 \pm 10 \%$ viable. Attempts to show upregulation of the $b c l-2$ transcript by IL-15 in fresh or starved NK cells was not technically possible. This was, however, demonstrable in the IL-15-dependent NK-92 cell line (20) that had been starved for $24 \mathrm{~h}$ and then incubated with IL-15 for $24 \mathrm{~h}$ (data not shown).

\section{Discussion}

The $\beta$ and $\gamma_{c}$ subunits of the IL-2R are critical for signaling through IL-2R and are constitutively expressed on NK cells. Mice that lack T cells, the source of IL-2, or bear a genetically disrupted IL-2 gene have NK cells. In contrast, mice that lack the $I L-2 R \gamma_{c}$ gene product or are treated with an anti-IL-2R $\beta$ $\mathrm{mAb}$ lack NK cells. These studies collectively suggest that a cytokine other than IL-2 that uses the IL- $2 \mathrm{R} \beta \gamma_{\mathrm{c}}$ is likely to be important for NK cell development and survival in vivo (7-12). IL-15 has no sequence homology to IL-2, yet uses the IL-2R $\beta \gamma_{c}$ complex to activate lymphoid cells $(13,16,17)$, and is constitutively expressed in a number of tissues including bone marrow 
stromal cells (14). For this reason, we undertook a study to determine if IL-15 could function as a survival factor for resting NK cells.

Using a CAT reporter construct in a heterologous tissue culture system, we confirmed earlier studies showing that coexpression of IL-15R $\alpha$ with IL- $2 \mathrm{R} \beta \gamma_{\mathrm{c}}$ is required to significantly enhance affinity for IL-15 $(18,19)$. Further, we demonstrated that this heterotrimeric complex is capable of transducing an intracellular signal at picomolar concentrations of IL-15, approximately a log-fold lower concentration of IL-15 than that required by the IL-2R $\beta \gamma_{c}$ heterodimeric or IL-2R $\alpha \beta \gamma_{c}$ heterotrimeric complex. The IL- $15 R \alpha \beta \gamma_{c}$ does not enhance signaling for IL-2. We have also provided the first evidence that fresh or resting NK cells express transcript for the IL-15R $\alpha$ chain and are functionally responsive to picomolar concentrations of IL-15. These data, along with our earlier Scatchard analysis of IL-15 binding on NK cells (16), provide strong evidence for the constitutive expression of a functional high affinity IL-15R complex on freshly isolated human NK cells.

Concentrations of IL-15 that selectively bind to the high affinity IL-15R $\alpha \beta \gamma_{c}$ can sustain human NK cell survival in vitro in the absence of serum or other growth factors. Analysis of cell morphology by light microscopy and DNA content via flow cytometry and gel electrophoresis all served to confirm that IL-15 sustains NK cell survival by preventing the early induction of apoptosis. This effect was dose dependent, and when IL-15 was used at low concentrations it was necessary to replenish cultures with cytokine on a daily basis to sustain NK cell survival for prolonged periods. Other monokines that activate NK cells and cytokines that use IL- $2 \mathrm{R} \gamma_{\mathrm{c}}$ but not IL-2R $\beta$ failed to support NK cell survival. These observations support the notion that NK cell homeostasis is likely to be continually dependent upon signals generated by the binding of ligand to the IL-2 $\beta \gamma_{c}$ complex (10-12). It is possible that other as yet undiscovered cytokines are capable of signaling via the IL-2R $\beta \gamma_{c}$ complex. Whether NK cell survival is supported by IL-15 alone or by a redundant system of cytokines will need to be determined experimentally through genetic disruption studies.

The absence of Bcl-2 expression in mice homozygous for the inactivation of $b c l-2$ results in a complete disappearance of lymphocytes by $6 \mathrm{wk}$ of postnatal life due to massive apoptosis $(31,32)$. Bcl-2 is therefore likely to be important for sustaining the survival of lymphocytes in their resting state. In this study, we show that IL-15 can maintain NK cell Bcl-2 protein expression and, using a bcl-2-specific antisense ODN, suggests that this may be one mechanism by which IL-15 promotes NK cell survival. Additional mechanisms may also be operative. It is possible that the absence of NK cells that results from genetic disruption of IL-2R $\gamma_{c}(10,11)$ or mAb blocking of IL-2R $\beta$ (12) may be due to an inability of cytokines such as IL-15 to maintain expression of the $b c l-2$ gene product. Studies to determine if IL- $2 \mathrm{R} \beta \gamma_{\mathrm{c}}$ signaling pathways are able to directly regulate transcription of the $b c l-2$ gene are currently under way.

\section{Acknowledgments}

We thank Dr. Michael Widmer and Dr. Elaine Thomas for critical reading of this manuscript.

This work was supported by National Institutes of Health grants CA-68326 (W.E. Carson), CA-39860 (C.M. Croce), CA-26122 (H. Baumann), and CA-70079 (M.A. Caligiuri). W.E. Carson is a recipient of the American Society of Clinical Oncology Young Investigator
Award. T.A. Fehniger is the recipient of the Howard Hughes Medical Institute Research Fellowship for Medical Students. We also wish to thank Karen K. Kuropatwinski for technical assistance with transfection experiments.

\section{References}

1. Robertson, M.J., and J. Ritz. 1990. Biology and clinical relevance of human natural killer cells. Blood. 76:2421-2438. 376 .

2. Trinchieri, G. 1989. Biology of natural killer cells. Adv. Immunol. 47:187-

3. Carson, W.E., S. Haldar, R.A. Baiocchi, C.M. Croce, and M.A. Caligiuri. 1994. The c-kit ligand suppresses apoptosis of human natural killer cells through the upregulation of bcl-2. Proc. Natl. Acad. Sci. USA. 91:7553-7557.

4. Voss, S.D., P.M. Sondel, and R.J. Robb 1992. Characterization of the interleukin 2 receptors (IL-2R) expressed on human natural killer cells activated in vivo by IL-2: association of the p64 $\gamma$ chain with the IL-2R $\beta$ chain in functional intermediate-affinity IL-2R. J. Exp. Med. 176:531-541.

5. Baume, D.M., M.J. Robertson, H. Levine, T.J. Manley, P.W. Schow, and J. Ritz. 1992. Differential responses to interleukin 2 define functionally distinct subsets of human natural killer cells. Eur. J. Immunol. 22:1-6.

6. Smith, K.A. 1988. Interleukin-2: inception, impact, and implications. Science (Wash. DC). 280:1169-1176.

7. Dorshkind, K., S.B. Pollack, M.J. Bosma, and R.A. Phillips. 1985. Natural killer (NK) cells are present in mice with severe combined immunodeficiency (scid). J. Immunol. 134:3798-3801.

8. Schorle, H., T. Holtschke, T. Hunig, A. Schimpl, and I. Horak. 1991. Development and function of $\mathrm{T}$ cells in mice rendered interleukin-2 deficient by gene targeting. Nature (Lond.). 352:621-624.

9. Kundig, T.M., H. Schorle, M.F. Bachmann, H. Hengarten, R.M. Zinkernagel, and I. Horak. 1993. Immune responses in interleukin-2-deficient mice. Science (Wash. DC). 262:1059-1061.

10. DiSanto, J.P., W. Maller, D. Guy-Grand, A. Fischer, and A. Rajewsky. 1995. Lymphoid development in mice with a targeted deletion of the interleukin 2 receptor $\gamma$ chain. Proc. Natl. Acad. Sci. USA. 92:377-381.

11. Noguchi, M., Y. Huafang, H.M. Rosenblatt, A.H. Filipovich, S. Adelstein, W.S. Modi, O.W. McBride, and W.J. Leonard. 1993. Interleukin-2 receptor $\gamma$ chain mutation results in X-linked severe combined immunodeficiency in humans. Cell. 73:147-157.

12. Tanaka T., F. Kitamura, Y. Nagasaka, K. Kuida, H. Suwa, and M. Miyasaka. 1993. Selective long-term elimination of natural killer cells in vivo by an anti-interleukin 2 receptor $\beta$ chain monoclonal antibody in mice. J. Exp. Med. 178:1103-1107.

13. Grabstein, K.H., J. Eisenman, K. Shanebeck, C. Rauch, S. Srinivasan, V. Fung, C. Beers, J. Richardson, M.A. Schoenborn, M. Ahdieh, et al. 1994. Cloning of a $\mathrm{T}$ cell growth factor that interacts with the $\beta$ chain of the interleukin-2 receptor. Science (Wash. DC). 264:965-968.

14. Mrózek, E., P. Anderson, and M.A. Caligiuri. 1996. Role of interleukin-15 in the development of human CD56+ natural killer cells from CD34+ hematopoietic progenitor cells. Blood. 87:2632-2640.

15. Carson, W.E., M.E. Ross, R.A. Baiocchi, M.J. Marien, M. Boiani, K. Grabstein, and M.A. Caligiuri. 1995. Endogenous production of interleukin 15 by activated human monocytes is critical for optimal production of interferon- $\gamma$ by natural killer cells in vitro. J. Clin. Invest. 96:2578-2582.

16. Carson, W.E., J.G. Giri, M.J. Lindemann, M.L. Linett, M. Ahdieh, D. Anderson, J. Eisenmann, K. Grabstein, and M.A. Caligiuri. 1994. Interleukin-15 is a novel cytokine which activates human natural killer cells via components of the interleukin-2 receptor. J. Exp. Med. 180:1395-1403.

17. Giri, J.G., M. Ahdieh, J. Eisenman, K. Shanebeck, K. Grabstein, L.S. Park, D. Cosman, and D. Anderson. 1994. Utilization of the $\beta$ and $\gamma$ chains of the IL-2 receptor by the novel cytokine IL-15. EMBO (Eur. Mol. Biol. Organ.) J. 13:2822-2830.

18. Giri, J.G., S. Kumaki, M. Ahdieh, D.J. Friend, A. Loomis, K. Shanebeck, R. Dubose, D. Cosman, L.S. Park, and D.M. Anderson. 1995. Identification and cloning of a novel IL-15 binding protein that is structurally related to the $\alpha$ chain of the IL-2 receptor. EMBO (Eur. Mol. Biol. Organ.) J. 14: 3654-3663.

19. Anderson, D.M., S. Kumaki, M. Ahdieh, J. Bertles, M. Tometsko, A. Loomis, J. Giri, N.G. Copeland, D.J. Gilbert, N.A. Jenkins, et al. 1995. Functional characterization of the human interleukin-15 receptor $\alpha$ chain and close linkage of IL-15R $\alpha$ and IL-2R $\alpha$ genes. J. Biol. Chem. 270:29862-29869.

20. Gong, J.H., G. Maki, and H.G. Klingemann. 1994. Characterization of a human cell line (NK-92) with phenotypical and functional characteristics of activated natural killer cells. Leukemia. 8:652-658.

21. Matos, M.E., G.S. Schnier, M.S. Beecher, L.K. Ashman, D.E. Williams, and M.A. Caligiuri. 1993. Expression of a functional c-kit receptor on a subset of natural killer cells. J. Exp. Med. 178:1079-1085.

22. Reed, J.C., C. Stein, C. Subasinghe, S. Haldar, C. Croce, S. Yum, and J. Cohen. 1990. Antisense-mediated inhibition of BCL2 protooncogene expression and leukemic cell growth and survival: comparisons of phosphodiester and 
phosphorothioate oligodeoxynucleotides. Cancer Res. 50:6565-6570.

23. Nicoletti, I., G. Migliorati, M.C. Pagliacci, F. Grignani, and C. Riccardi. 1991. A rapid and simple method for measuring thymocyte apoptosis by propidium iodide staining and flow cytometry. J. Immunol. Methods. 139:271-279.

24. Chromczynski, P., and N. Sacchi. 1987. Single step method of RNA isolation by acid guanidinium thiocyanate-phenol-chloroform extraction. Anal. Biochem. 162:156-159.

25. Knowles, B.B., C.C. Howe, and D.P. Aden. 1980. Human hepatocellular carcinoma cell lines secrete the major plasma proteins and hepatitis B surface antingen. Science (Wash. DC). 209:497-499.

26. Graham, F.L., and A.J. Van der Eb. 1973. A new technique for the assay of infectivity of human adenovirus 5 DNA. Virology. 52:456-467.

27. Morella, K., C.-F. Lai, S. Kumaki, N. Kumaki, Y. Wang, E.M. Bluman, B.A. Witthuhn, J.N. Ihle, J. Giri, D.P. Gearing, et al. 1995. The action of interleukin 2 receptor subunits define a new type of signaling mechanism for hematopoietin receptors in hepatic cells and fibroblasts. J. Biol. Chem. 270:82988310 .
28. Nakari, T., M.J. Robertson, M. Streuli, Z. Wu, T.L. Ciardelli, K.A. Smith, and J. Ritz. 1994. Interleukin 2 receptor gamma chain expression on resting and activated lymphoid cells. J. Exp. Med. 180:241-251.

29. Lin, J.-X., T.-S. Migone, M. Tsang, M. Freidmann, J.A. Weatherbee, L. Zhou, A. Yamauchi, E.T. Bloom. J. Meitz, S. John, et al. 1995. The role of shared receptor motifs and common stat proteins in the generation of cytokine pleiotropy and redundancy by IL-2, IL-4, IL-7, IL-13, and IL-15. Immunity. 2: 331-339.

30. Wyllie, A.H. 1980. Glucocorticoid-induced thymocyte apoptosis is associated with endogenous endonuclease activation. Nature (Lond.). 284:555-556.

31. Veis, D.J., C.M. Sorenson, J.R. Shutter, and S.J. Korsmeyer. 1993. Bcl-2-deficient mice demonstrate fulminant lymphoid apoptosis, polycystic kidneys, and hypopigmented hair. Cell. 75:229-240.

32. Nakayama, K., K.-I. Nakayama, I. Negishi, K. Kuida, H. Sawa, D.Y. Loh. 1994. Targeted disruption of the Bcl-2 gene in mice: Occurrence of gray hair, polycystic kidney disease, and lymphocytopenia. Proc. Natl. Acad. Sci. USA. 91:3700-3706. 